
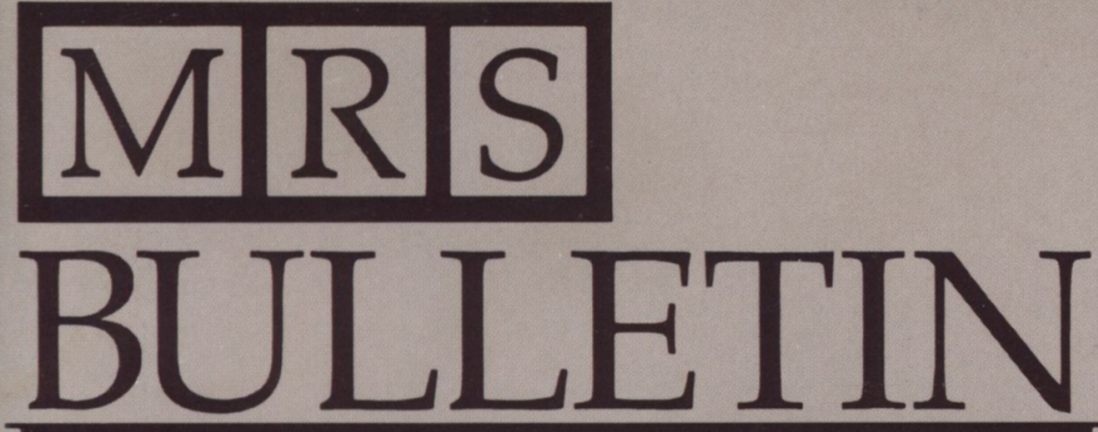

Serving the International Materials Research Community

A Publication of the Materials Research Society

September 1992, Volume XVII, No. 9

MEMBER OF

TInUment

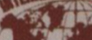

(2)

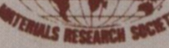

\title{
Materials Education
}




\section{September 1992}

A Publication of the Materials Research Society

Volume XVII, Number 9 ISSN: 0883-7694 CODEN: MRSBEA

MATERIALS EDUCATION

18 Materials Science and Engineering Education

R. Abbaschian, Guest Editor

22 “Materials" Education: The Second Time Around R. Roy

27 Materials Science and Technology: A Model for Achieving National Education Goals I.D. Hays

32 Will the Integration of Materials Science into Engineering Core Undergraduate Curricula Ever be Complete-Is the "Chemistry" Right?

J. R. Ambrose

36 Problems in Engineering and Science Education: Why Do We Have a Weakness in Materials Synthesis and Processing? T.W. Eagar

39 Initiating New Academic Programs in Materials Science

M.V. Mundschau

42 Graduate Education for Materials Scientists and Engineers: General, Special or Fundamental?

Phillip J. Stiles

\section{DEPARTMENTS}

5 Material Matters

7 Resources

8 Research/Researchers

12 From Washington

47 Education Exchange

49 Historical Note

50 Calendar

53 Upcoming Conferences

53 Classified

53 Advertisers in This Issue

55 Posterminaries

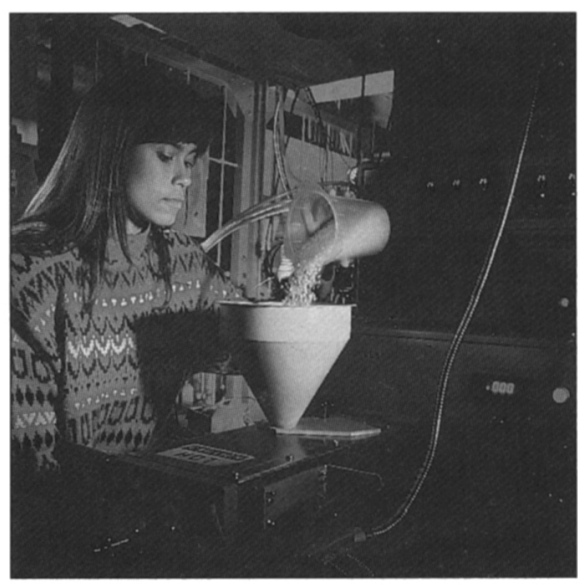

ON THE COVER: Ingrid Liedermooy, a Materials Science and Engineering student at the University of Florida, pours polystyrene pellets into the hopper in preparation to extrude molten polystyrene as part of her education in processing of materials. See the articles beginning on p. 18 for more information about materials education. Photo by David Blankenship. 
Materials Research Society • 9800 McKnight Road • Pittsburgh, PA 15237

\section{About the Materials Research Society}

The Materials Research Society (MRS), a nonprofit scientific association founded in 1973, promotes interdisciplinary goal-oriented basic research on materials of technological importance. Membership in the Society includes more than 10,000 scientists, engineers, and research managers from industrial, government, and university research laboratories in the United States and more than 40 countries.

The Society's interdisciplinary approach differs from that of single-discipline professional societies because it promotes information exchange across the many technical fields touching materials development. MRS sponsors two major international annual meetings encompassing approximately 50 topical symposia, and also sponsors numerous single-topic scientific meetings. The Society recognizes professional and technical excellence, conducts short courses, and fosters technical interaction in local geographic regions through Sections and University Chapters.

MRSparticipates in theinternational arena of materials research through the International Union of Materials Research Societies (IUMRS). MRS is an affiliate of the American Institute of Physics.

MRS publishes symposium proceedings, MRS Bulletin, Journal of Materials Research, and other publications related to current research activities.

MRS Bullctin (ISSN: 0883-7694) is published 12 times a year by the Materials Research Society, 9800 McKnight Road, Pittsburgh, PA 15237. Application to mail at second class rates has been approved at Pittsburgh, PA and at additional mailing offices. POSTMASTER: Send address changes to MRS Bulletin in care of the Materials Research Society, at the address listed phone (412) 367-3003; Fax (412) 367-4373

Membership in MRS is $\$ 70$ annually for regular members, \$25 for students and retired members. Dues include an allocation of $\$ 25$ ( $\$ 15$ for students and retirees) to a subscription to MRS Bulletirr. Individual member subscriptions are for personal use only. Non-member subscription rates are $\$ 95$ for one calendar year (12 issues) within the U.S.A. and $\$ 140$ elsewhere. Single copies may be purchased for $\$ 15$ each. Send subscription orders toSubscription Department Materials Research Society, 9800 McKnight Road, P'ittsburgh, PA 15237.

MRS Bulletin is included in Current Contents/Plusical, Chemical \& Earth Sciences' $^{\mathrm{T}}$, Research Alert, and the Materials Science Citation Index ${ }^{\mathrm{TM}}$. Back volumes of MRS Bulletin are available in $16 \mathrm{~mm}$ microfilm, $35 \mathrm{~mm}$ microfilm, or $105 \mathrm{~mm}$ microfiche through University Microfilms Inc. 300 North Zeeb Road, Ann Arbor, Michigan 48106

\section{MRS BULLETIN}

Publisher

G. A. Oare

Technical Editor

E. L. Fleischer

Assistant Editor

J. M. Guenther

Copy Editors

L. A. Krysinski, D. M. Varner

Art Director

C. Love

Design/Production

S. Franklin, B. Wyant

CHAIRMAN-EDITORIAL BOARDS

E. N. Kaufmann • Argonne National Laboratory • Argonne, Illinois, USA

INTERNATIONALADVISORY BOARD

\section{Balkansk}

University of Pierre and Marie Curie

Paris, France

R. G. Elliman

Australian National University

Canberra, Australia

S. Hsu

Chung Shan Institute of Science

and Technology

Taiwan, China

TECHNICAL EDITORIAL BOARD

Editorial Assistants

E.M. Benec, M. M. Costello,

J. Dininny

Advertising and Circulation

M. E. Kaufold

Associate Editor-Europe

I. W. Boyd

University College London

Dept. of Electronic and

Electrical Engineering

Torrington Place

London WCI E7 JE

United Kingdom

$71-387-7050$ ext. 3956 or 7304
Editorial and Advertising Offices

9800 McKnight Road

Pittsburgh, PA 15237

Telephone (412)-367-3036

Fax (412) 367-4373

MRS Office of Public Affairs

1630 Connecticut Ave. NW

Washington, DC 20009

Telephone (202) 483-6771

Guest Editor

R. Abbaschian

Special Contributors

K.J. Anderson, J.Di Benedetto

R.A. Frosch

L. C. Ianniello
U. S. Department of Energy
Washington, DC, USA
H-D. Li
National Science Foundation-China
Beijing, China
P. Rama Rao
Ministry of Science and
Technology
New Delhi, India

R. Roy

Pennsylvania State University

University Park, Pennsylvania, USA

T. Sugano

Toyo University

Tokyo, dapan

D. L. Weaire

University of Dublin

Dublin, Ireland

\section{F. Y. Fradin}

Argonne National Laboratory

Argonne, Illinois, USA

B. M. Léon

Universidade de Vigo

Vigo, Spain

G. L. Liedl

Purdue University

West Lafayette, Indiana, USA

\section{J. C. Bravman}

Stanford University

Stanford, California, USA

C. W. Draper

AT\&T Engineering Research Center

Princeton, New Jersey, USA

E. Fogarassy

Centre de Recherches Nucléaires

Strasbourg, France

\author{
S. Namba \\ Osaka University \\ Osaka, Japan \\ A. D. Romig Jr \\ Sandia National Laboratories \\ Albuquerque, New Mexico, USA \\ J. Soares \\ Universidade de Lisboa \\ Lisboa, Portugal \\ K. C. Taylor \\ General Motors Research Laboratories \\ Warren, Michigan, USA \\ W. H. Sutton \\ United Technologies \\ Research Center \\ East Hartford, Connecticut \\ C. W. White \\ Oak Ridge National Laboratory \\ Oak Ridge, Tennessee
}

MRS BULLETIN PUBLICATIONS SUBCOMMITTEE

A. Barkatt

Catholic University of America

Washington, DC

A. J. Hurd

Sandia National Laboratories

Albuquerque, New Mexico

M. R. Libera

Stevens Institute of Technology

Hoboken, New Jersey

\section{G. J. McCarthy}

North Dakota State University

Fargo, North Dakota

J. M. Phillips

AT\&T Bell Laboratories

Murray Hiil, New Jersey

S. M. Prokes

Naval Research Laboratory

Washington, DC

\section{MRS EXECUTIVE COMMITTEE}

\section{President}

G. S. Cargill III

IBM T. J. Watson Research Center

First Vice President and President-Elect

S. T. Picraux

Sandia National Laboratories

Second Vice President

J. C. Bravman

Stanford University

\author{
Secretary \\ L. A. Boatner \\ Oak Ridge National Laboratory \\ Treasurer \\ C. B. Duke \\ Xerox Research Laboratories \\ Rodney C. Ewing \\ University of New Mexico, USA \\ Tel. (505) 277-4163; Fax (505) 277-0090
}

ry

Immediate Past President

J. B. Roberto

Oak Ridge National Laboratory

Executive Director

Materials Research Society

John B. Ballance

\section{Secretary}

Treasurer

Shigeyuki Sōmiya

Nishi Tokyo University, Japan

Tel. (81) 3417 2866; Fax (81) 34156619

\section{INTERNATIONAL UNION OF MATERIALS RESEARCH SOCIETIES}

President

R. P. H. Chang

Northwestern University, USA

Tel. (708) 491-3598; Fax (708) 491-4181
Vice President

Paul Siffert

Centre de Recherches Nucléaires, France

Tel. (88) 2865 43; Fax (88) 280990

\section{IUMRS ADHERING BODIES}

Australian Materials Science Committee (AMSC) J. S. Williams

Chinese Materials Research Society (C-MRS) Hengde Li

European Materials Research Society (E-MRS) B. Stritzker
Materials Research Society (MRS)

G. S. Cargill III

Materials Research Society of India (MRS-I)

C. N. R. Rao

Materials Research Society of Japan (MRS-J)

Masaki Hasegawa
Materials Research Society of Korea (MRS-Korea) Min Che Chon

Materials Research Society of Taiwan (MRS-T) Li-chung Lee

Mexican Materials Research Society (Mexican MRS) M. J. Yacaman 


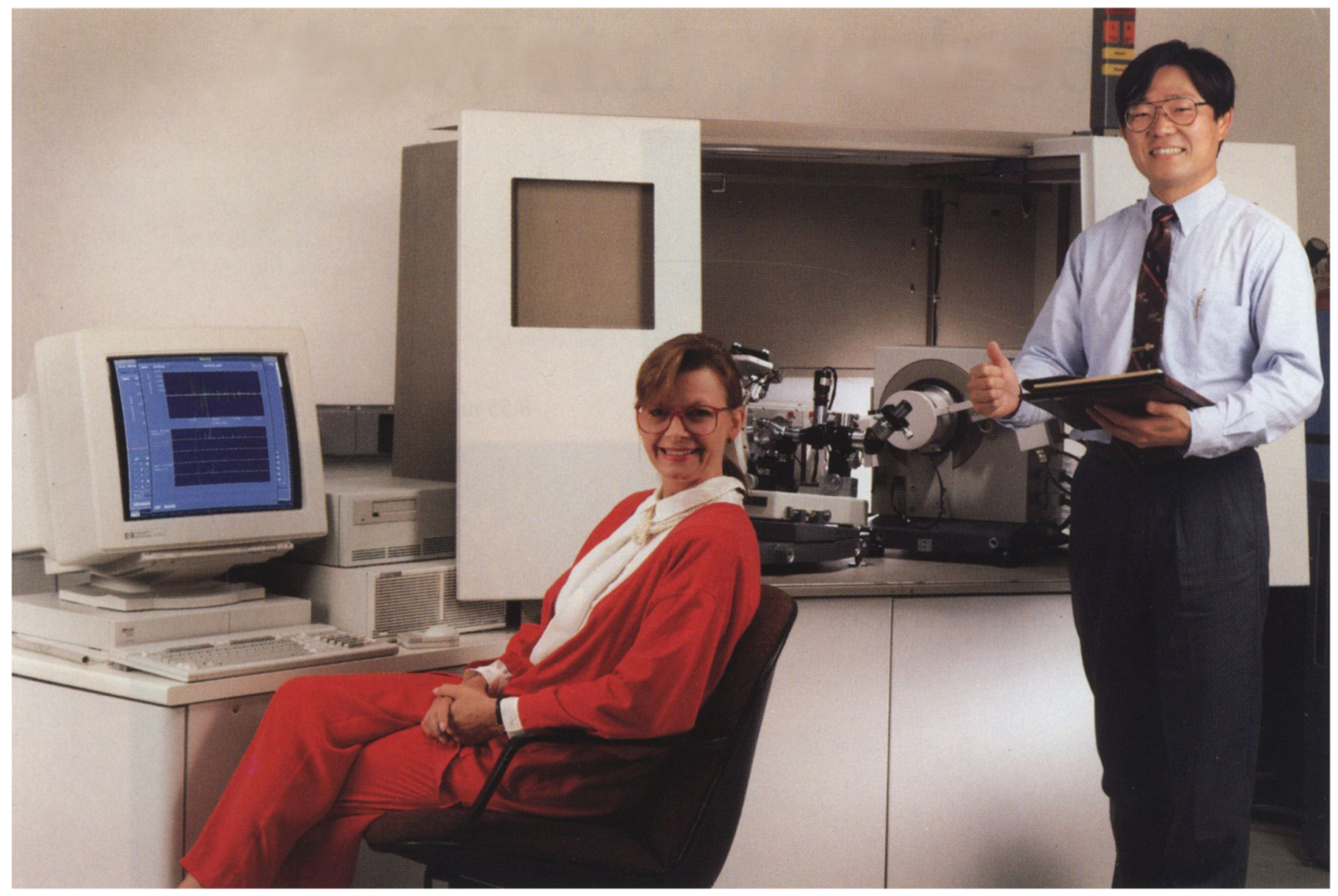

\section{Why are Rigaku D/MAX-1000 Diffractometers the preferred choice?}

\section{The Reasons Are Clear.}

\section{Full Automation}

Goniometer alignment, monochromator control, and slit selection fall into place with a single stroke of the keyboard. No other diffractometer offers such ease of use.

\section{New UNIX-Based Software}

Operating in a windows environment, the redesigned system boasts multiple multis. These include multi-tasking, multi-user open access, multi-windows, multi-menus and graphics screen controls, multi-benefits, and multi-costeffectiveness.

\section{Focus on Specific Needs}

The D/MAX-1000 series offers a line of diffractometers that make consistent measurements unparalleled in accuracy and reproducibility. $\mathrm{D} / \mathrm{MAX}-1000$ focuses on what is needed without all the gizmos and doodads that no one ever uses anyway. The system is designed for the precise requirements and comfort level of the individual user.

Whatever your analysis needs, there is a $D / M A X-1000$ suited for you. Choose from:

\section{- Vertical \\ - Horizontal \\ - Theta Theta \\ Contact our XRD Specialists}

Learn more about the Rigaku D/MAX-1000 series and how they can provide the solutions to your analytical requirements. We develop the best diffractometers in the world, but our most important products are solutions for our customers.

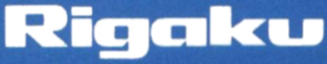

Rigaku/USA, Inc.

Northwoods Business Park 200 Rosewood Drive Danvers, MA 01923 USA (508) 777-2446

FAX (508) 777-3594 


\section{Probe the Atomic World . . .}

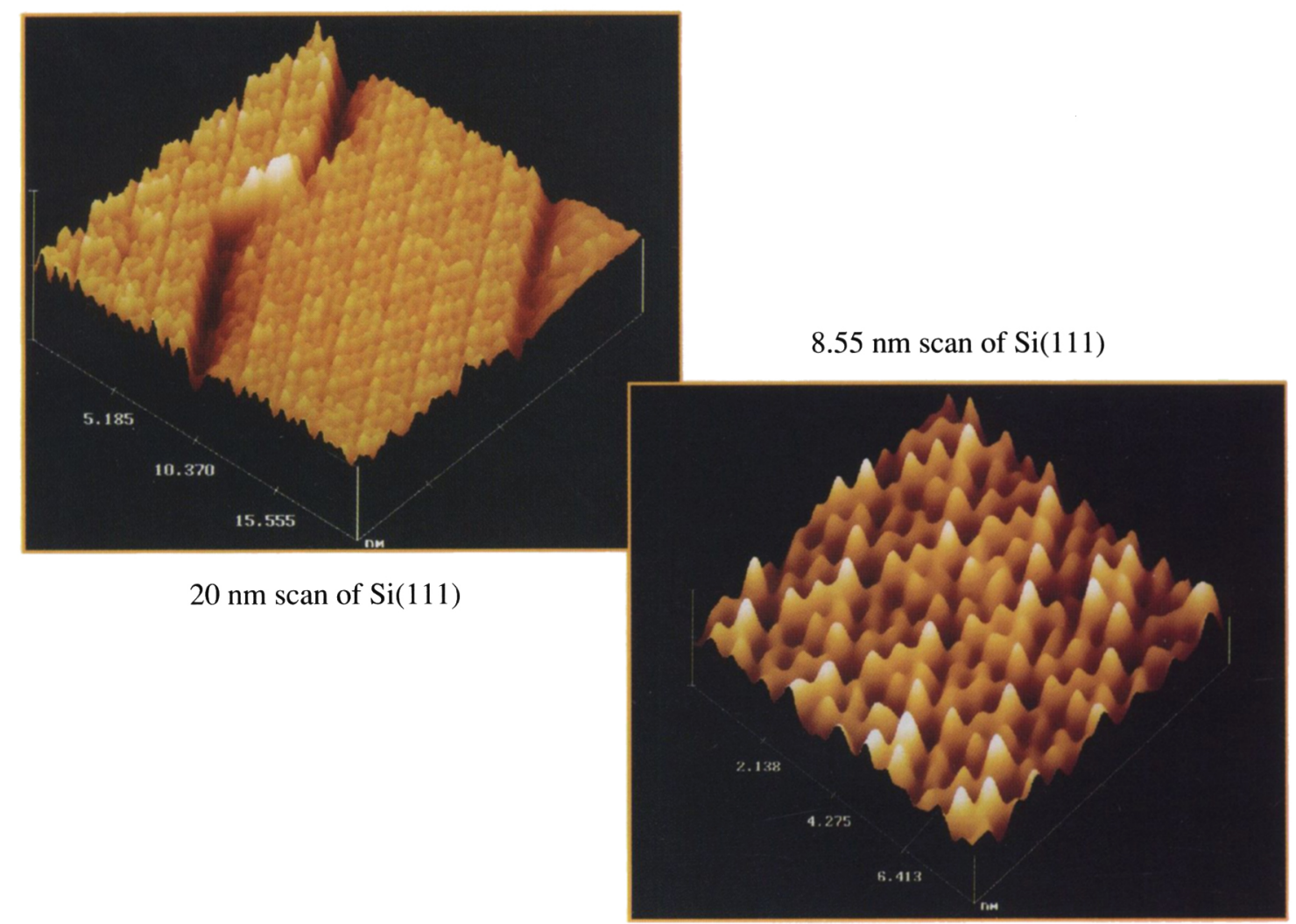

\section{With Perkin-Elmer and Digital Instruments}

SURFACE ANALYSIS

Introducing the new $\mathrm{PHI}^{\circledR}$ UHV NanoScope ${ }^{\circledR} 301$ STM

Perkin-Elmer, Physical Electronics (PHI) and Digital Instruments have joined forces to bring you a new ultrahigh vacuum (UHV) Scanning Tunneling Microscope (STM).

Combining the imaging capabilities of a scanning tunneling microscope with the cleanliness and stability of an ultrahigh vacuum environment, the PHI UHV NanoScope 301 STM will provide you with atomic images of structures that are not possible when using an STM in air.

The PHI UHV NanoScope 301 STM features a new magnetic tip exchange mechanism, a choice of three interchangeable scan heads, and digital feed-

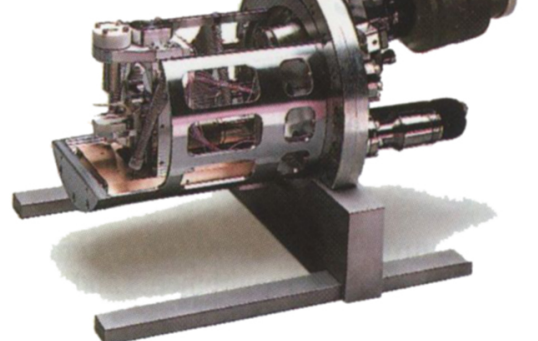

back control electronics and software created by Digital Instruments (DI). So you can image single crystals. Perform large scale scans. Exchange tips without breaking vacuum. And get the performance, control, and convenience you need to expand your analytical capabilities.

You can use the PHI UHV NanoScope 301 STM alone, as an addition to our surface analysis systems, or with DI's NanoScope III air microscope.

For a free brochure, write or call us at 612-828-6421. Or fax us your request at 612-828-6322.

\section{PERKIN ELMER}

